\title{
Article \\ Synthesis of Methyl Mercaptan on Mesoporous Alumina Prepared with Hydroxysafflor Yellow A as Template: The Synergistic Effect of Potassium and Molybdenum
}

\author{
Chuang Peng ${ }^{1,2,+}$, Dong Zeng ${ }^{1,+}$, Jianjun Li $^{3}$, Shuai Peng ${ }^{1}$, Jun Xiong ${ }^{1}$, Weiming Wang ${ }^{1, *(\mathbb{D}, \text { Yingming Chen }}{ }^{4}$, \\ Hong Liu ${ }^{4}$, Hao Liu ${ }^{5}$ and Rui Qin ${ }^{4, *}$
}

1 Hubei Provincial Engineering Laboratory for Clean Production and High Value Utilization of Bio-Based Textile Materials, Wuhan Textile University, Wuhan 430200, China; pengchuang@hrbeu.edu.cn (C.P.); d201980168@hust.edu.cn (D.Z.); gwzps211@126.com (S.P.); jxiong@wtu.edu.cn (J.X.)

2 College of Materials Science and Chemical Engineering, Harbin Engineering University, Harbin 150001, China 3 College of Chemistry and Chemical Engineering, Xiamen University, Xiamen 361005, China; 1jj716@163.com

4 College of Resource and Environmental Science, South-Central University for Nationalities,

Wuhan 430074, China; chen_yingming@126.com (Y.C.); liuhong@mail.scuec.edu.cn (H.L.)

5 State Key Laboratory of Coal Combustion, Huazhong University of Science and Technology, Wuhan 430074, China; liuhao@hust.edu.cn

* Correspondence: wangweiming1212@163.com (W.W.); qinrui@mail.scuec.edu.cn (R.Q.)

+ These authors contributed equally to this work and should be considered co-first authors.

check for

updates

Citation: Peng, C.; Zeng, D.; Li, J.; Peng, S.; Xiong, J.; Wang, W.; Chen, Y.; Liu, H.; Liu, H.; Qin, R. Synthesis of Methyl Mercaptan on Mesoporous Alumina Prepared with Hydroxysafflor Yellow A as Template: The Synergistic Effect of Potassium and Molybdenum. Catalysts 2021, 11, 1365. https:// doi.org/10.3390/catal11111365

Academic Editor: Weijian Diao

Received: 12 October 2021

Accepted: 9 November 2021

Published: 13 November 2021

Publisher's Note: MDPI stays neutral with regard to jurisdictional claims in published maps and institutional affiliations.

Copyright: (c) 2021 by the authors. Licensee MDPI, Basel, Switzerland. This article is an open access article distributed under the terms and conditions of the Creative Commons Attribution (CC BY) license (https:// creativecommons.org/licenses/by/ $4.0 /)$.
Abstract: K-promoted Mo-based catalysts showed great promise for the hydrogenation of $\mathrm{CS}_{2}$ to methyl mercaptan $\left(\mathrm{CH}_{3} \mathrm{SH}\right)$. However, the research on the synergistic effect of $\mathrm{K}$ and $\mathrm{Mo}$, and the active site of $\mathrm{CS}_{2}$ hydrogenation to $\mathrm{CH}_{3} \mathrm{SH}$ were unexplored widely. To solve this problem, the synergistic effect of $\mathrm{K}$ and $\mathrm{Mo}$ in the $\mathrm{K}$-promoted Mo-based catalysts for $\mathrm{CS}_{2}$ hydrogenation to prepare $\mathrm{CH}_{3} \mathrm{SH}$ was investigated. The mesoporous alumina was the support and loaded the active components potassium and molybdenum to prepare the catalyst. The results suggested that the active components $\mathrm{K}$ and Mo can not only cooperatively regulate the acid-base sites on the catalyst surface, but also stabilize the molybdate species at +5 valence during the reduction process and increase the Mo unsaturated coordination sites. Combined with the results of the catalytic activity evaluation, indicating that the main active site of the catalysts is the weak Lewis acid-base site, and the strong acidic site and strong alkaline site are not conducive to the formation of $\mathrm{CH}_{3} \mathrm{SH}$. Moreover, the possible catalytic mechanism of $\mathrm{CS}_{2}$ hydrogenation to $\mathrm{CH}_{3} \mathrm{SH}$ on the weak Lewis acid-base sites of the catalysts was proposed. The research results of this paper can provide an experimental basis and theoretical guidance for the design of high-performance $\mathrm{CH}_{3} \mathrm{SH}$ synthesis catalyst and further mechanism research.

Keywords: methyl mercaptan; $\mathrm{CS}_{2}$; alumina; synergistic effect; $\mathrm{KMo} / \mathrm{Al}_{2} \mathrm{O}_{3}$

\section{Introduction}

Methanethiol, also known as methyl mercaptan $\left(\mathrm{CH}_{3} \mathrm{SH}\right)$, is one of the raw materials for the industrial production of methionine. At present, methyl mercaptan is mainly synthesized by methanol thiolation $\left(\mathrm{CH}_{3} \mathrm{OH}-\mathrm{H}_{2} \mathrm{~S}\right.$ method) in industry [1-6], which has some disadvantages, such as high reaction temperature $\left(340 \sim 400{ }^{\circ} \mathrm{C}\right)$, many byproducts, and serious three wastes. More and more researchers are mainly focused on finding a more economical and environmentally friendly synthesis routes in recent years. Among them, the catalytic synthesis of $\mathrm{CH}_{3} \mathrm{SH}$ from sulfur-containing synthesis gas has aroused great interest among researchers [7-14], but the conversion and yield of $\mathrm{CH}_{3} \mathrm{SH}$ are relatively low, which does not meet the requirements of large-scale industrialization. $\mathrm{CS}_{2}$ is relatively surplus and the price is low at present, and the one-step synthesis of $\mathrm{CH}_{3} \mathrm{SH}$ by $\mathrm{CS}_{2}$ hydrogenation has the advantages of low reaction temperature $\left(260 \sim 280{ }^{\circ} \mathrm{C}\right)$ and fewer 
three wastes. At present, the study of one-step synthesis of $\mathrm{CH}_{3} \mathrm{SH}$ from carbon disulfide $\left(\mathrm{CS}_{2}\right)$ hydrogenation is rare [15-17]. Therefore, it is necessary to synthesis of $\mathrm{CH}_{3} \mathrm{SH}$ by one-step hydrogenation of $\mathrm{CS}_{2}$, which not only has positive significance in promoting and enriching the synthesis of $\mathrm{CH}_{3} \mathrm{SH}$ but also can realize clean production, which has good economic and social value.

In the field of catalytic synthesis of methanethiol, transition metal sulfides are generally considered to be the main active phase $[10,11,14,17-20]$. Among them, $\mathrm{MoS}_{2}$-based catalysts promoted by alkali metals have potential application prospects because of their unique properties, such as sulfur resistance, not ease to coking and avoiding expensive deep desulfurization in industry, which have been also widely used in water-gas shift [21-24], syngas to higher alcohols [25-30], hydrodesulfurization [31-34] and hydrogenation [35-38]. The research results of active phase $\mathrm{MoS}_{2}$ in these fields can also provide some reliable basis for the synthesis of $\mathrm{CH}_{3} \mathrm{SH}$. For example, for the synthesis of higher alcohols from syngas, it is generally believed that the synthesis of higher alcohols mainly occurs on the $\mathrm{MoS}_{2}$ phase promoted by alkali metals, while the pure $\mathrm{MoS}_{2}$ phase is beneficial to the formation of hydrocarbons. The Johannes A. Lercher research group $[16,18]$ found a similar view in the process of catalytic synthesis of $\mathrm{CH}_{3} \mathrm{SH}$ from carbonyl sulfide. It is considered that the catalyst used has two active phases named the pure $\mathrm{MoS}_{2}$ phase and the potassiumdecorated $\mathrm{MoS}_{2}$ phase. The synthesis of $\mathrm{CH}_{3} \mathrm{SH}$ mainly occurs on the potassium-decorated $\mathrm{MoS}_{2}$ phase, while the pure $\mathrm{MoS}_{2}$ phase is beneficial to the formation of by-products. Since the 1990s, Yang's group has carried out a detailed study on the catalytic synthesis of $\mathrm{CH}_{3} \mathrm{SH}$ from sulfur-containing syngas [8,9,39-42]. Supported molybdate potassium oxide (Mo-O-K) and molybdenum sulfide potassium (Mo-S-K) catalysts supported on silica and modified catalysts containing $\mathrm{Ni}, \mathrm{Co}$ and Te promoters were developed. The relationship between the preparation method of the catalyst, the optimization of active components, the optimization of reaction conditions, and the catalytic performance was systematically studied, and the mechanism of synthesis of $\mathrm{CH}_{3} \mathrm{SH}$ from sulfur-containing syngas over $\mathrm{MoS}_{\mathrm{x}}-\mathrm{K}^{+}$catalyst was proposed [8]. It is considered that the by-product methane is easily formed in the $\mathrm{MoS}_{2}$ active phase, while the $\mathrm{CH}_{3} \mathrm{SH}$ is formed in the Mo-S-K active phase.

Herein, to further insight the effect of active components potassium and molybdenum on the selectivity of $\mathrm{CH}_{3} \mathrm{SH}$ and how they cooperate in the synthesis of $\mathrm{CH}_{3} \mathrm{SH}$, we chose mesoporous alumina $\left(\mathrm{Al}_{2} \mathrm{O}_{3}\right)$ as the support and loaded active components potassium and molybdenum to prepare catalysts to study the one-step synthesis of $\mathrm{CH}_{3} \mathrm{SH}$ by $\mathrm{CS}_{2}$ hydrogenation. The mesoporous alumina was prepared in an aqueous system using hydroxysafflor yellow A derived from safflower as a template. In recent years, our research group has been committed to the research and application development of safflower $[43,44]$. Due to its unique molecular framework rigidity and reaction with metal ions, hydroxysafflor yellow A in safflower is expected to be used as an ideal template for the preparation of mesoporous alumina in an aqueous system. For $\mathrm{K}-\mathrm{Mo} / \mathrm{Al}_{2} \mathrm{O}_{3}$ catalyst, $\mathrm{K}$ and Mo loading and their molar ratio are in the optimal range for $\mathrm{CS}_{2}$ hydrogenation to $\mathrm{CH}_{3} \mathrm{SH}$. The results of the catalytic activity evaluation showed that the selectivity of by-product $\mathrm{CH}_{3} \mathrm{SCH}_{3}$ was higher when the catalyst was loaded with a single active component, for example, the selectivity of $\mathrm{CH}_{3} \mathrm{SCH}_{3}$ was as high as $92.9 \%$ at $260{ }^{\circ} \mathrm{C}$ on the $\mathrm{K} / \mathrm{Al}$ catalyst. When $\mathrm{K}$ and Mo were introduced simultaneously, the selectivity of $\mathrm{CH}_{3} \mathrm{SH}$ increased rapidly, and it reached $91.2 \%$ at $260{ }^{\circ} \mathrm{C}$ over the $\mathrm{K}-\mathrm{Mo} / \mathrm{Al}$ catalyst. Moreover, the synergistic effect of $\mathrm{K}$ and Mo was discussed, and the possible catalytic mechanism for the hydrogenation of $\mathrm{CS}_{2}$ to $\mathrm{CH}_{3} \mathrm{SH}$ on the active site was proposed.

\section{Results and Discussion}

\subsection{Catalytic Performances of the Catalysts}

The relationship between the selectivity of the products and the reaction temperature over $\mathrm{Al}, \mathrm{Mo} / \mathrm{Al}, \mathrm{K} / \mathrm{Al}$, and $\mathrm{K}-\mathrm{Mo} / \mathrm{Al}$ catalysts is shown in Figure 1 . Since the conversion of $\mathrm{CS}_{2}$ is $100 \%$ in the whole reaction temperature range, it is not shown in the figure. It can be seen from Figure 1 that the $\mathrm{Al}_{2} \mathrm{O}_{3}(\mathrm{Al})$ itself is a highly active catalyst for the hydrogenation 
of $\mathrm{CS}_{2}$. For $\mathrm{Al}$ catalyst, the selectivity of $\mathrm{CH}_{3} \mathrm{SH}, \mathrm{CH}_{3} \mathrm{SCH}_{3}$ and $\mathrm{CH}_{4}$ was $31.5 \%, 67.5 \%$ and $1 \%$ at $260{ }^{\circ} \mathrm{C}$, respectively. When the active component Mo is introduced, the changing trend of the selectivity of the products is similar to that of $\mathrm{Al}$ catalyst with the increase of reaction temperature, except that the selectivity of $\mathrm{CH}_{3} \mathrm{SCH}_{3}$ decreases slightly, while the selectivity of $\mathrm{CH}_{3} \mathrm{SH}$ increases slightly. As far as $\mathrm{K} / \mathrm{Al}$ catalyst is concerned, it can be concluded that the addition of potassium alone can greatly reduce the selectivity of $\mathrm{CH}_{3} \mathrm{SCH}_{3}$, while increasing the selectivity of $\mathrm{CH}_{3} \mathrm{SH}$, that is, the addition of potassium promotes the disproportionation of $\mathrm{CH}_{3} \mathrm{SH}$ to $\mathrm{CH}_{3} \mathrm{SCH}_{3}$, which is especially significant at low temperature $\left(\mathrm{T}<300^{\circ} \mathrm{C}\right)$. When potassium and molybdenum were introduced into the support at the same time, the selectivity of $\mathrm{CH}_{3} \mathrm{SH}$ was greatly improved over $\mathrm{K}-\mathrm{Mo} / \mathrm{Al}$ catalyst, and the selectivity of $\mathrm{CH}_{3} \mathrm{SH}$ reached $91.2 \%$, the selectivity of $\mathrm{CH}_{4}$ was only $0.1 \%$ at $260{ }^{\circ} \mathrm{C}$; even at $300{ }^{\circ} \mathrm{C}$, the selectivity of $\mathrm{CH}_{3} \mathrm{SH}$ was $85.8 \%$, and the selectivity of $\mathrm{CH}_{4}$ was $1.5 \%$; which shows that the disproportionation and further hydrogenation process of methyl mercaptan are inhibited with the addition of potassium and molybdenum. In addition, for all catalysts, the selectivity of $\mathrm{CH}_{4}$ increases with the increase of reaction temperature, which is consistent with the reports in the literature $[15,16]$. For example, the selectivity of $\mathrm{CH}_{4}$ on $\mathrm{K}-\mathrm{Mo} / \mathrm{Al}$ catalysts is $0.1 \%, 1.5 \%, 9.5 \%$, and $25.2 \%$ at 260, 300, 340 and $380{ }^{\circ} \mathrm{C}$, respectively, which increased about 16.8 times from 300 to $380{ }^{\circ} \mathrm{C}$ (Figure S1). To sum up, we can conclude: when the active component potassium or molybdenum is introduced alone, it is not conducive to the formation of $\mathrm{CH}_{3} \mathrm{SH}$, and when potassium and molybdenum are added at the same time, potassium and molybdenum can play a synergistic catalytic role and jointly promote the formation of $\mathrm{CH}_{3} \mathrm{SH}$.

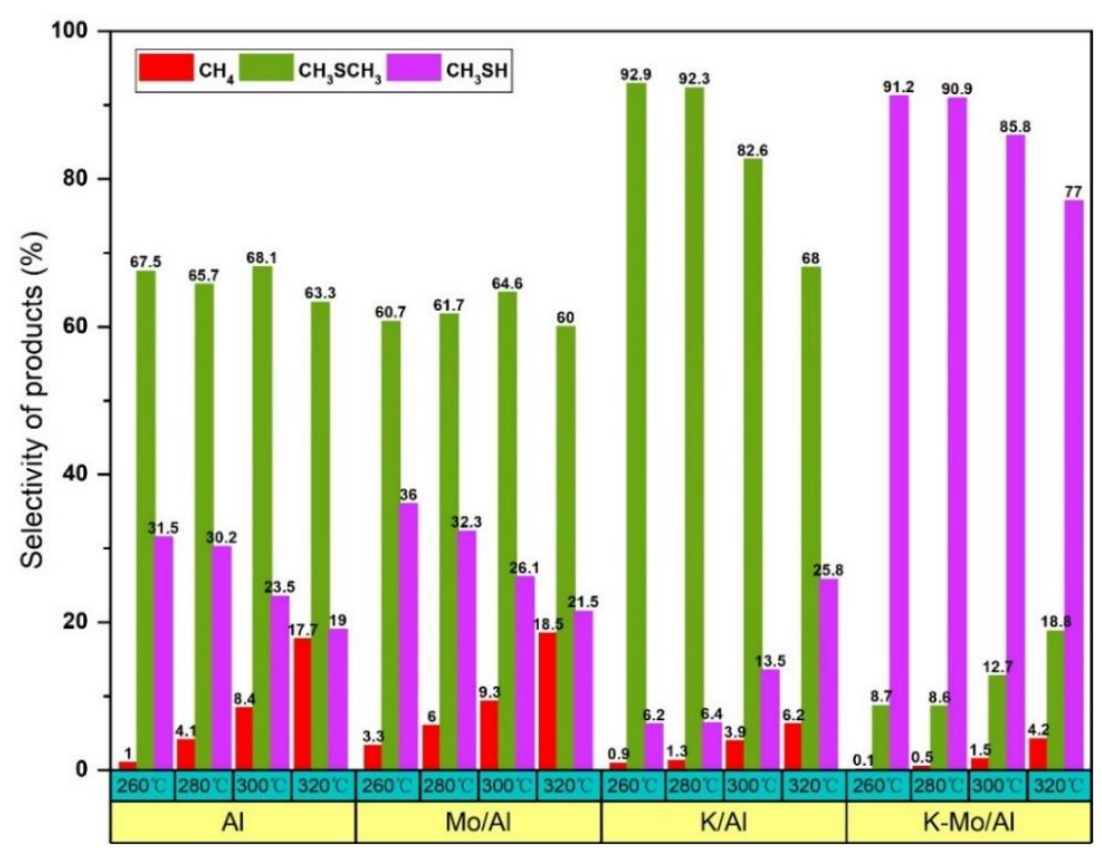

Figure 1. The selectivities toward $\mathrm{CH}_{4}, \mathrm{CH}_{3} \mathrm{SCH}_{3}$ and $\mathrm{CH}_{3} \mathrm{SH}$ as a function of reaction temperature over the $\mathrm{Al}, \mathrm{Mo} / \mathrm{Al}, \mathrm{K} / \mathrm{Al}$ and $\mathrm{K}-\mathrm{Mo} / \mathrm{Al}$ catalysts. Reaction conditions: $p=0.3 \mathrm{MPa}$, $\mathrm{R}\left(\mathrm{CS}_{2}\right)=1.6 \mathrm{~mL} / \mathrm{h}, \mathrm{R}\left(\mathrm{H}_{2}\right)=30 \mathrm{~mL} / \mathrm{min}, 2 \mathrm{~mL}$ of the Catalyst.

\subsection{Textural Properties}

The fundamental physical and chemical properties of $\mathrm{Al}, \mathrm{Mo} / \mathrm{Al}, \mathrm{K} / \mathrm{Al}$ and $\mathrm{K}-\mathrm{Mo} / \mathrm{Al}$ catalysts, including BET specific surface area, pore volume and average pore size, are shown in Figure 2. It can be seen from the figure that the specific surface area and pore volume of alumina decrease rapidly with the addition of potassium and molybdenum. For instance, the specific surface area and pore volume of alumina (Al) are $327 \mathrm{~m}^{2} \cdot \mathrm{g}^{-1}$ and $0.41 \mathrm{~cm}^{3} \cdot \mathrm{g}^{-1}$ respectively, while that of the $\mathrm{K}-\mathrm{Mo} / \mathrm{Al}$ catalyst are $196 \mathrm{~m}^{2} \cdot \mathrm{g}^{-1}$ and $0.31 \mathrm{~cm}^{3} \cdot \mathrm{g}^{-1}$ respectively, which may be largely due to the increase of catalyst density 
after the addition of potassium and molybdenum, causing the surface area per unit mass is reduced. At the same time, it was found that the average pore size increased with the addition of potassium and molybdenum, which were 2.55, 2.98, 3.64 and $2.99 \mathrm{~nm}$ respectively on $\mathrm{Al}, \mathrm{Mo} / \mathrm{Al}, \mathrm{K} / \mathrm{Al}$ and $\mathrm{K}-\mathrm{Mo} / \mathrm{Al}$ catalysts, which may be due to the formation of some large particle species with the introduction of potassium and molybdenum during the preparation of the catalyst, resulting in some small pores being blocked.

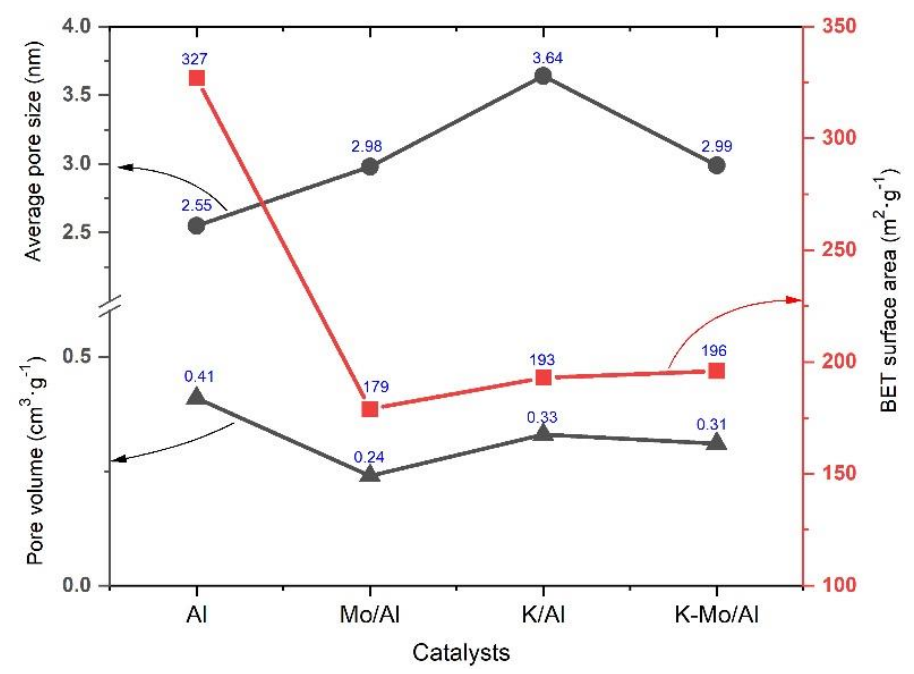

Figure 2. The textural parameters of $\mathrm{Al}, \mathrm{Mo} / \mathrm{Al}, \mathrm{K} / \mathrm{Al}$ and $\mathrm{K}-\mathrm{Mo} / \mathrm{Al}$ catalysts.

\subsection{Crystalline Phase and Morphology}

The crystalline phases of $\mathrm{Al}, \mathrm{Mo} / \mathrm{Al}, \mathrm{K} / \mathrm{Al}$ and $\mathrm{K}-\mathrm{Mo} / \mathrm{Al}$ catalysts before and after reaction were characterized by $\mathrm{X}$-ray diffraction, the $\mathrm{XRD}$ patterns are shown in Figure 3. Because the crystalline phase of pure alumina (Al) does not change before and after the reaction, the spectra of the spent $\mathrm{Al}$ are not listed in the diagram. The diffraction peak of $\mathrm{Al}_{2} \mathrm{O}_{3}$ was detected on all the catalysts [JCPDS File Number: 00-029-0063]. The diffraction peaks of $2 \theta=12.5,23.3,25.5,27.3,33.5,35.5$ and $56.3^{\circ}$ belonging to $\mathrm{MoO}_{3}$ [JCPDS File Number: 00-005-0508] were detected on the fresh Mo/Al catalyst, while on the spent $\mathrm{Mo} / \mathrm{Al}$ catalyst, there were mainly diffraction peaks belonging to $\mathrm{MoS}_{2}$ [JCPDS File Number: 00-024-0513], and the diffraction peak belonging to $\mathrm{MoO}_{2}$ [JCPDS File Number: 01-078-1070] was detected at $2 \theta=26^{\circ}$ at the same time. In the case of the $\mathrm{K} / \mathrm{Al}$ catalyst, the diffraction peaks of $\mathrm{K}_{2} \mathrm{Al}_{19} \mathrm{O}_{29.5}$ [JCPDS File number: 00044-1009] and $\mathrm{K}_{2} \mathrm{O}$ [JCPDS File number: 01-089-5956] were detected on the fresh catalyst, which was consistent with the results of the scanning electron microscope (Figure $4 \mathrm{~b}$ ). The results of SEM showed that new species were formed on the surface of the $\mathrm{K} / \mathrm{Al}$ catalyst. However, only the diffraction peak belonging to $\mathrm{K}_{2} \mathrm{SO}_{4}$ [JCPDS File Number: 00-0030608] was detected on the spent catalyst. When potassium and molybdenum were introduced at the same time, no diffraction peaks belonging to potassium and molybdenum species were detected on the fresh $\mathrm{K}-\mathrm{Mo} / \mathrm{Al}$ catalyst, indicating that they were amorphous or highly dispersed on the surface of $\gamma-\mathrm{Al}_{2} \mathrm{O}_{3}$, which was consistent with the results of the corresponding EDS mapping images (Figure $4 \mathrm{e}-\mathrm{h}$ ). While on the spent $\mathrm{K}-\mathrm{Mo} / \mathrm{Al}$ catalyst, diffraction peaks belonging to $\mathrm{MoS}_{2}$ and $\mathrm{K}_{2} \mathrm{SO}_{4}$ were detected at the same time. According to the report of references [16,18], the active phase $\mathrm{MoS}_{2}$ phase is formed during the pre-sulfurization process, while the $\mathrm{K}_{2} \mathrm{SO}_{4}$ phase is formed through the intermediates $\mathrm{K}_{2} \mathrm{MoS}_{4}$ and $\mathrm{K}_{2} \mathrm{~S}$ in the activity evaluation process. The sulfided $\mathrm{K}_{2} \mathrm{MoS}_{4}$ is first transformed into $\mathrm{K}_{2} \mathrm{~S}$, and then the irreversible reaction between $\mathrm{K}_{2} \mathrm{~S}$ and oxygen-containing species leads to the accumulation of the $\mathrm{K}_{2} \mathrm{SO}_{4}$ phase. Whereas, we did not detect the diffraction peaks of $\mathrm{K}_{2} \mathrm{MoS}_{4}$ and $\mathrm{K}_{2} \mathrm{~S}$ species in the XRD diffraction pattern, indicating that $\mathrm{K}_{2} \mathrm{MoS}_{4}$ and $\mathrm{K}_{2} \mathrm{~S}$ species are highly dispersed on the alumina support. In addition, we did not perform a pre-sulfurization process for the catalysts before evaluating the activity of the catalysts, 
indicating the catalysts can be sulfided by using sulfur-containing raw materials and product $\mathrm{H}_{2} \mathrm{~S}$ in the reaction process. Finally, on the spent $\mathrm{Mo} / \mathrm{Al}$ catalyst, not only the diffraction peak of $\mathrm{MoS}_{2}$ species was detected, but also the diffraction peak belonging to $\mathrm{MoO}_{2}$ species was detected, demonstrating molybdenum oxide had not been completely sulfided at this time.

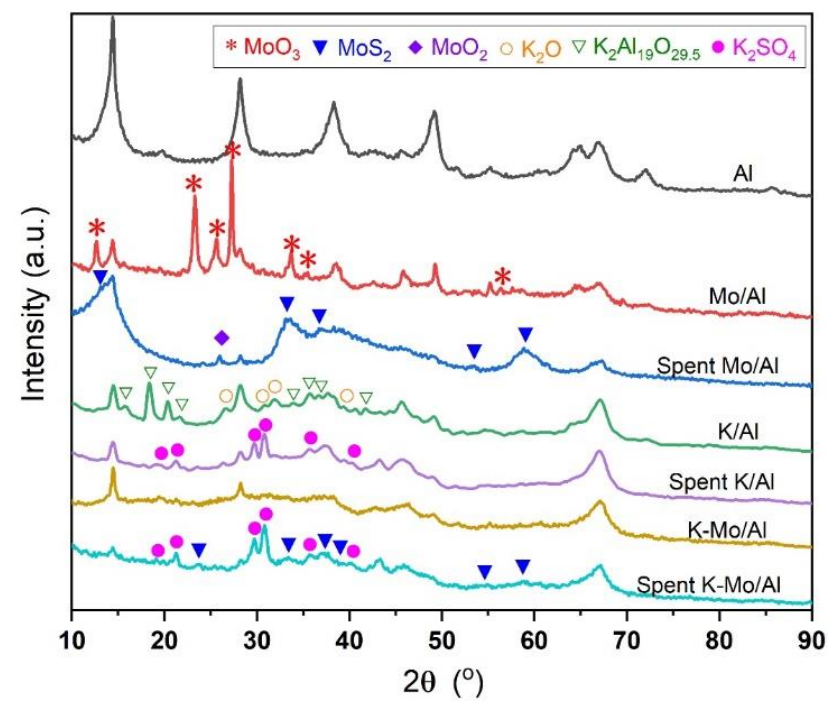

Figure 3. XRD diffraction patterns of the fresh catalysts and the spent catalysts.
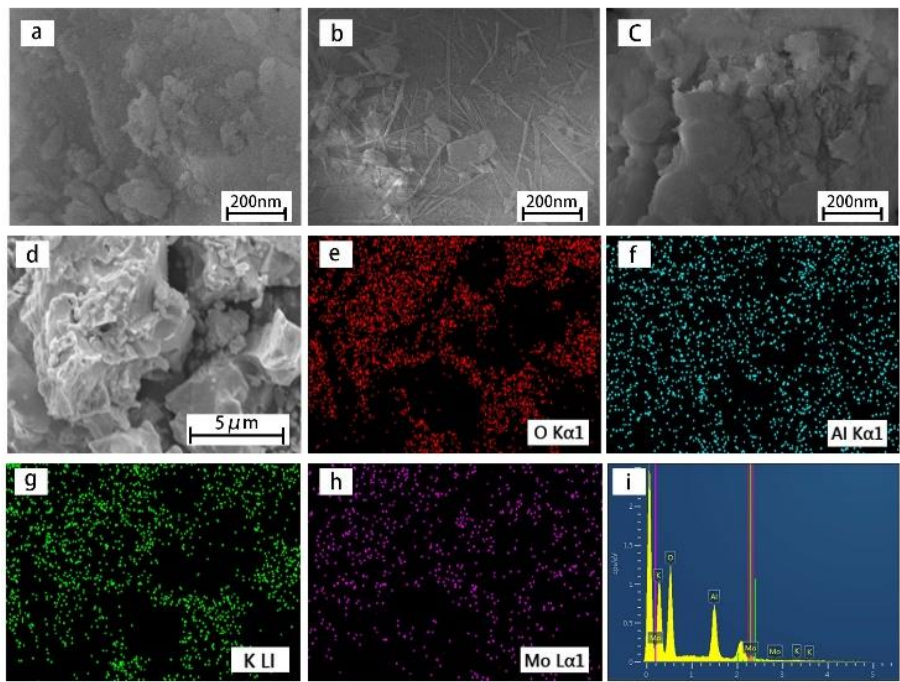

Figure 4. (a) SEM image of the fresh $\mathrm{Mo} / \mathrm{Al}$ catalyst, (b) SEM image of the fresh $\mathrm{K} / \mathrm{Al}$ catalyst, (c) SEM image of the fresh K-Mo/Al catalyst, (d) SEM image of the fresh $\mathrm{K}-\mathrm{Mo} / \mathrm{Al}$ catalyst and the corresponding EDS mapping images for $\mathrm{O}(\mathbf{e}), \mathrm{Al}(\mathbf{f}), \mathrm{K}(\mathbf{g})$ and $\mathrm{Mo}(\mathbf{h})$, (i) EDS spectra of the fresh $\mathrm{K}-\mathrm{Mo} / \mathrm{Al}$ catalyst.

\section{4. $\mathrm{H}_{2}$-TPR Studies}

The $\mathrm{H}_{2}$-TPR characterization of the fresh catalysts is shown in Figure 5. It can be seen that, in terms of $\mathrm{Al}_{2} \mathrm{O}_{3}$, there is a weak low-temperature peak at $202{ }^{\circ} \mathrm{C}$ and a wide overlapping peak in the range of $250 \sim 600{ }^{\circ} \mathrm{C}$ which is mainly attributed to the reduction process of $\mathrm{Al}$ species. When the active component is loaded, the low-temperature peak shifts to low temperature, while the wide overlapping peak shifts to a higher temperature, indicating that the interaction between the active component and the $\mathrm{Al}_{2} \mathrm{O}_{3}$ support becomes stronger after loading the active component and a new $\mathrm{H}_{2}$ consumption peak appears at $633{ }^{\circ} \mathrm{C}$ on the Mo-containing catalysts, which is attributed to the reduction of Mo 
species. For the attribution of the reduction peak, it is generally believed that Mo species exist in two states: one is a highly dispersed state (monolayer dispersed structure), and the other is aggregated state (double layer or multilayer structure). Monolayer dispersed Mo-O species are easier to be reduced than double-multilayer dispersed Mo-O species. Brito et al. [45] observed two kinds of reduction peaks on $\mathrm{MoO}_{3} / \mathrm{Al}_{2} \mathrm{O}_{3}$ catalysts named $\mathrm{Mo}_{\mathrm{I}}\left(455-500{ }^{\circ} \mathrm{C}\right)$ and $\mathrm{Mo}_{\text {II }}\left(780-860{ }^{\circ} \mathrm{C}\right)$. The former belongs to the partial reduction of Mo species with high dispersion, while the latter belongs to the deep reduction of this species and the reduction of Mo species which are more difficult to reduce (such as tetrahedral coordination Mo species). Feng et al. [46] found that the low-temperature reduction peak can be attributed to the reduction process of +6 to +4 valence of octahedral coordination $\mathrm{Mo}(\mathrm{Oh})$ species, and the high-temperature reduction peak is the reduction process of +6 to +4 valence of tetrahedral coordination $\mathrm{Mo}(\mathrm{Td})$ species. It should be pointed out that the distribution of Mo species on the support is often affected by preparation methods, such as the properties of the support, molybdenum precursors, calcination conditions, and other factors. When the temperature is less than $800{ }^{\circ} \mathrm{C}$, the supported molybdenum-oxygen catalyst can't be reduced to the metal state $[46,47]$. It is generally believed that the molybdenum oxygen species on the support mainly exist in the form of tetrahedral coordination and octahedral coordination, and the molybdenum oxygen species with tetrahedral coordination structures are difficult to be reduced [48]. To sum up, for the $\mathrm{Mo} / \mathrm{Al}$ and $\mathrm{K}-\mathrm{Mo} / \mathrm{Al}$ catalysts in this paper, the $\mathrm{H}_{2}$ consumption peak in the range of $250 \sim 500{ }^{\circ} \mathrm{C}$ can be classified as the Mo (VI) $\rightarrow$ Mo (IV) reduction process of octahedral molybdenum oxygen species, and at 550 800 ${ }^{\circ} \mathrm{C}$, it can be attributed to the $\mathrm{Mo}(\mathrm{VI}) \rightarrow \mathrm{Mo}(\mathrm{IV})$ reduction process of tetrahedral molybdenum species. With the addition of alkali auxiliaries, the surface Mo-O species structure has changed, so that the surface Mo-O structure is more transformed into a tetrahedral structure, and the octahedral coordinated Mo-O species decreases. For the $\mathrm{H}_{2}$ consumption peak of K-Mo/ Al catalyst at low temperature $\left(250 \sim 500{ }^{\circ} \mathrm{C}\right)$, the two splitting peaks may be attributed to the Mo (VI) $\rightarrow \mathrm{Mo}(\mathrm{V}) \rightarrow \mathrm{Mo}$ (IV) reduction process of octahedral molybdenum species, indicating the addition of alkali can stabilize Mo-O species at +5 valence during the reduction process, which is consistent with the results reported in reference [49,50]. The effect of alkali is considered to delay the reduction of Mo. Chen et al. [51] believe that the addition of alkali strengthens the Mo-O bond and leads to the increase of reduction activation energy.

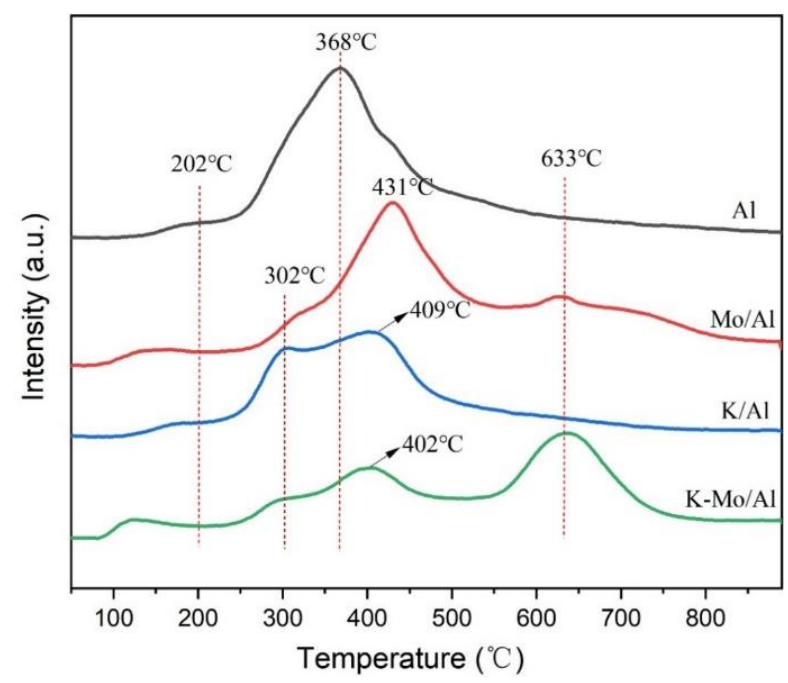

Figure 5. $\mathrm{H}_{2}$-TPR spectra of the fresh catalysts.

\subsection{Surface Acid-Base Properties}

The acid-base sites on the surface of the catalysts are often determined by $\mathrm{CO}_{2} / \mathrm{NH}_{3}$ TPD. From the $\mathrm{CO}_{2}$-TPD spectrum (Figure 6a), it can be seen that all the catalysts have a $\mathrm{CO}_{2}$ desorption peak attributed to the weak base center at about $100^{\circ} \mathrm{C}$. There are only 
weak basic sites on $\mathrm{Al}, \mathrm{Mo} / \mathrm{Al}$ and $\mathrm{K}-\mathrm{Mo} / \mathrm{Al}$ catalysts, and the quantities of weak base sites decrease greatly when the active component Mo is introduced alone, but when $\mathrm{K}$ and Mo are introduced at the same time, the quantities of weak base sites is slightly more than that of the Al catalyst. For the $\mathrm{K} / \mathrm{Al}$ catalyst, due to the addition of strong basic components, a wide overlapping $\mathrm{CO}_{2}$ desorption peak belonging to weak, medium and strong basic sites appeared. In addition, according to the $\mathrm{NH}_{3}-\mathrm{TPD}$ spectrum (Figure $6 \mathrm{~b}$ ), there are weak, medium and strong acid sites on the surface of the four catalysts, and their relative quantities are summarized in Table 1. Combining the activity evaluation result of the catalyst, it can be considered that strong acid sites and strong base sites are not conducive to the selectivity of methyl mercaptan.
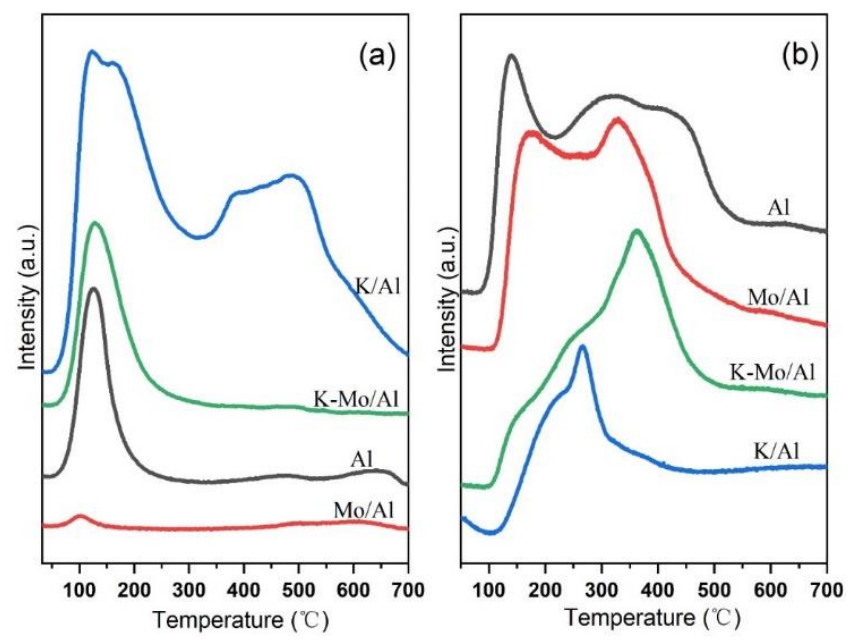

Figure 6. TPD spectra of the catalysts, (a) $\mathrm{CO}_{2}-\mathrm{TPD},(\mathbf{b}) \mathrm{NH}_{3}$-TPD.

Table 1. The quantity distribution of acid-basic sites on the surface of the catalysts.

\begin{tabular}{ccccccccc}
\hline \multirow{2}{*}{ Catalysts } & \multicolumn{3}{c}{$\begin{array}{c}\text { Basic Site Distribution from } \\
\text { CO }_{2} \text {-TPD [a] }\end{array}$} & \multicolumn{4}{c}{$\begin{array}{c}\text { Acid Site Distribution from } \\
\text { NH }_{3} \text {-TPD [a] }\end{array}$} \\
\cline { 2 - 9 } & Weak & Medium & Strong & Total & Weak & Medium & Strong & Total \\
\hline $\mathrm{Al}$ & 1.0 & - & - & 1.0 & 0.41 & 0.34 & 0.25 & 1.0 \\
$\mathrm{Mo} / \mathrm{Al}$ & 0.03 & - & - & 0.03 & 0.53 & 0.40 & 0.33 & 1.26 \\
$\mathrm{~K} / \mathrm{Al}$ & 3.67 & 1.84 & 2.35 & 7.86 & 0.26 & 0.11 & 0.03 & 0.4 \\
$\mathrm{~K}-\mathrm{Mo} / \mathrm{Al}$ & 1.42 & - & - & 1.42 & 0.14 & 0.15 & 0.28 & 0.57 \\
\hline
\end{tabular}

[a] The quantity of acid sites and basic sites of $\mathrm{Al}$ catalyst is defined as 1.0, and other catalysts are compared with it.

The surface acidic sites of the catalysts can also be characterized by pyridine adsorption infrared spectroscopy. As shown in Figure 7, there are five characteristic peaks with different intensities at 1612,1593,1577, 1490 and $1444 \mathrm{~cm}^{-1}$, respectively, which are attributed to the different adsorption forms of pyridine on alumina [52]. The absorption peaks at 1612 and $1593 \mathrm{~cm}^{-1}$ belong to the $8 \mathrm{a}$ ring vibration mode of the coordination bond between pyridine and Lewis acid site, which belongs to the strong Lewis acid site [4]. When the active component Mo was introduced, a new pyridine desorption peak belonging to the Brønsted acid site appeared at $1540 \mathrm{~cm}^{-1}$, and the intensity of the pyridine desorption peak belonging to the Lewis acid site increased. When $\mathrm{K}$ is introduced, all the pyridine adsorption peaks shift to low wavenumber, which may be due to the strong interaction between $\mathrm{K}$ and the $\mathrm{Al}_{2} \mathrm{O}_{3}$ support [4]. The quantities of Lewis acid sites are in the following order: $\mathrm{Mo} / \mathrm{Al}>\mathrm{Al}>\mathrm{K} / \mathrm{Al}>\mathrm{K}-\mathrm{Mo} / \mathrm{Al}$. In addition, the intensity of pyridine desorption peak on the surface of $\mathrm{K} / \mathrm{Al}$ and $\mathrm{K}-\mathrm{Mo} / \mathrm{Al}$ catalysts decreased with the increase of desorption temperature, and pyridine was desorbed completely on $\mathrm{K} / \mathrm{Al}$ and $\mathrm{K}-\mathrm{Mo} / \mathrm{Al}$ catalysts at $250{ }^{\circ} \mathrm{C}$ (Figure S2), indicating that the Lewis acid on the surface of $\mathrm{K} / \mathrm{Al}$ and $\mathrm{K}-\mathrm{Mo} / \mathrm{Al}$ catalysts is mainly a weak Lewis acid site. 


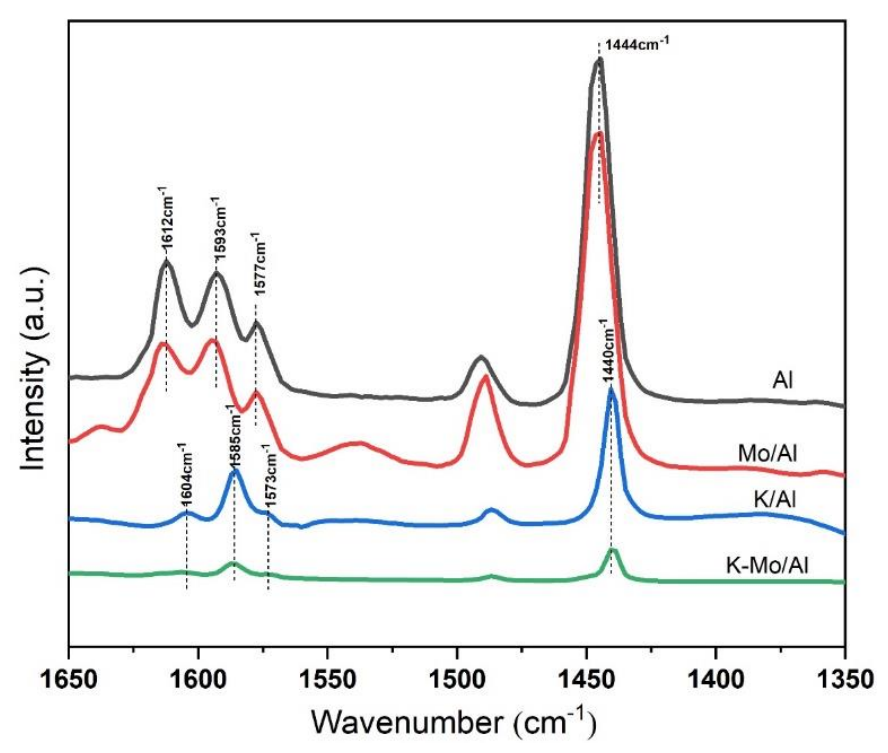

Figure 7. Spectra of pyridine adsorbed on the catalysts at $50{ }^{\circ} \mathrm{C}$.

\subsection{XPS Study of Catalysts}

The XPS spectra of Mo/Al and K-Mo/Al were shown in Figure 8. The peaks of binding energy at $\sim 229, \sim 231$ and $\sim 232.7 \mathrm{eV}$ represent the $+4,+5$, and +6 valence states of Mo, respectively, and the acromion at $226.6 \mathrm{eV}$ is the peak of $\mathrm{S}(2 \mathrm{~s})[53,54]$. Molybdenum species on fresh catalysts are present mainly in the form of $\mathrm{Mo}^{6+}$, and $\mathrm{Mo}^{4+}$ appears after the reaction, which is consistent with the results of XRD experiments (Figure 3). $\mathrm{MoS}_{2}$ $\left(\mathrm{Mo}^{4+}\right)$ was detected in XRD experiments on both $\mathrm{Mo} / \mathrm{Al}$ and $\mathrm{K}-\mathrm{Mo} / \mathrm{Al}$ catalysts after the reaction.

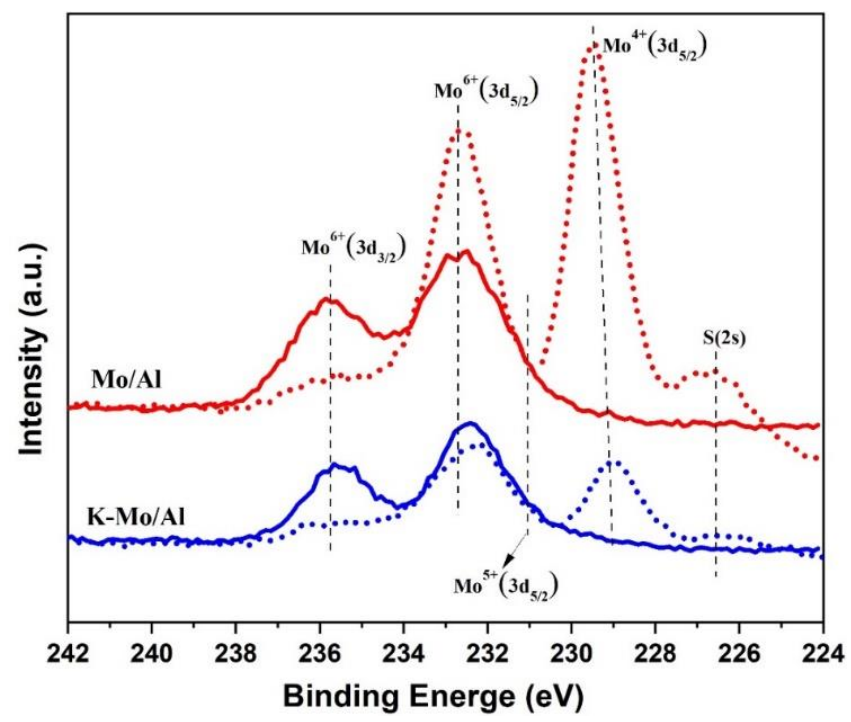

Figure 8. Mo(3d) XPS spectra of the fresh catalysts (Solid line) and the spent catalysts (Dashed line).

The fitting results of the Mo(3d) XPS spectra are shown in Figure 9, and the quantitative results are shown in Table 2. From the results of Table 2, it can be seen that the addition of potassium affects the valence equilibrium among Mo species, increasing the concentration of $\mathrm{Mo}^{5+}$ species and decreasing the concentration of $\mathrm{Mo}^{4+}$ species on the sulfided $\mathrm{K}-$ $\mathrm{Mo} / \mathrm{Al}$ catalyst, reducing the reducibility of $\mathrm{K}-\mathrm{Mo} / \mathrm{Al}$ catalyst, which was consistent with the characterization results of $\mathrm{H}_{2}$-TPR. The research results $[46,48,55]$ show that the Mo-O species mainly have octahedral and tetrahedral configurations, and tetrahedral configurations are more difficult to reduce and sulfurization than octahedral configurations. 
Due to the interaction between $\mathrm{K}$ and Mo, some octahedral species are transformed into tetrahedral species, so the addition of potassium reduces the reducibility of molybdenum species, resulting in that the $\mathrm{Mo}^{5+}$ species being more stable on the $\mathrm{K}-\mathrm{Mo} / \mathrm{Al}$ catalyst, while the $\mathrm{Mo}^{4+}$ species is more likely to be formed on the $\mathrm{Mo} / \mathrm{Al}$ catalyst, which is consistent with the results reported by Kantschewa et al. [55] and Ozkan et al. [50]. Some scholars [51] believe that the addition of alkaline auxiliaries inhibits the reducibility of $\mathrm{MoO}_{3}$, and the existence of alkali enhances the bond energy of the $\mathrm{Mo}-\mathrm{O}$ bond and increases the activation energy of reduction.
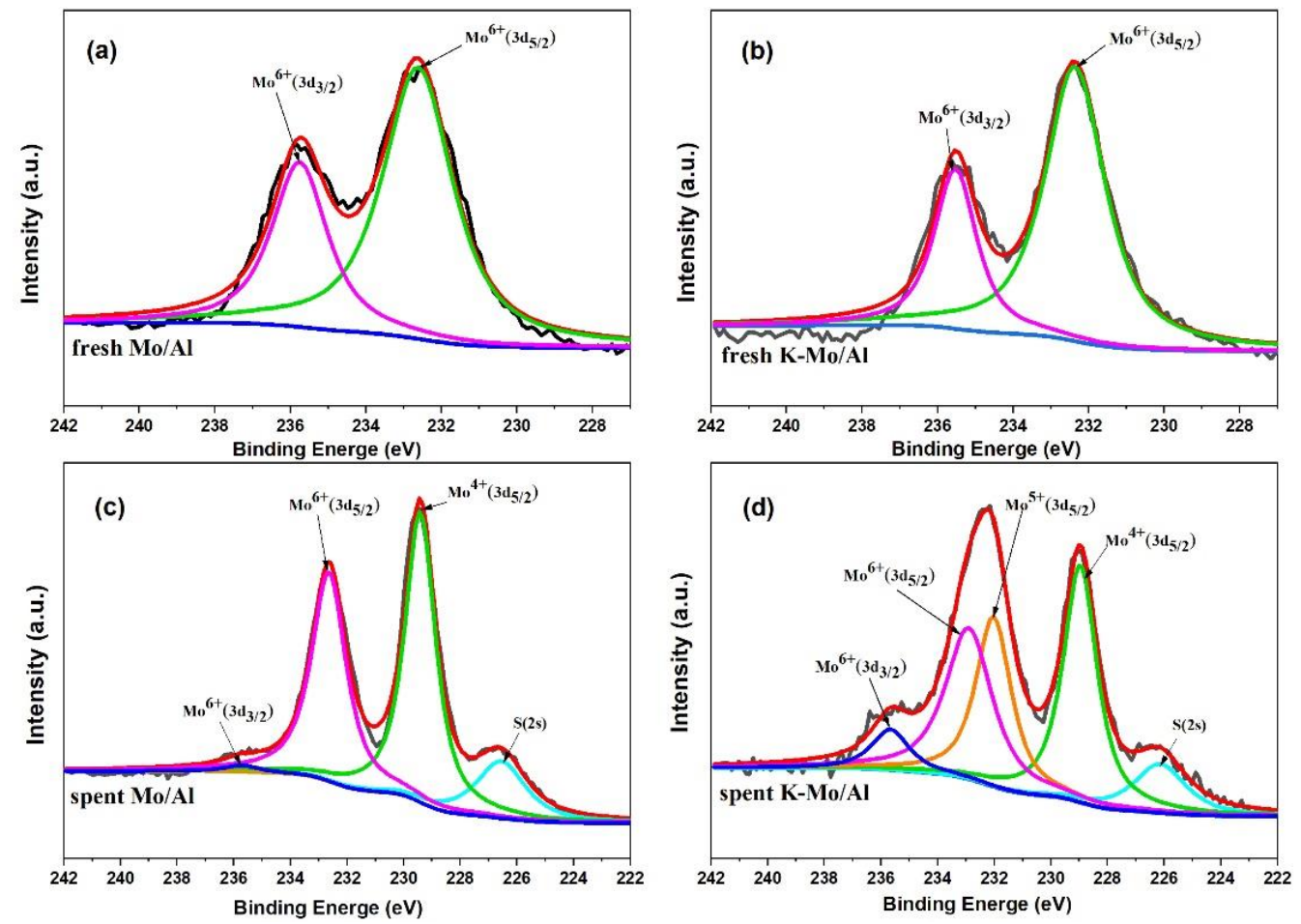

Figure 9. The fitting curves of $\mathrm{Mo}(3 \mathrm{~d})$ XPS spectra of (a) fresh $\mathrm{Mo} / \mathrm{Al}$, (b) fresh $\mathrm{K}-\mathrm{Mo} / \mathrm{Al}$, (c) spent $\mathrm{Mo} / \mathrm{Al}$ and (d) spent K-Mo/Al.

Table 2. The fitting results of Mo(3d) XPS spectra of the spent catalysts.

\begin{tabular}{|c|c|c|c|c|c|c|}
\hline \multirow{2}{*}{ Catalysts } & \multicolumn{3}{|c|}{ Binding Energy of Mo( $\left(3 d_{5 / 2}\right) e V$} & \multicolumn{3}{|c|}{ Concentration (\%) } \\
\hline & $\mathrm{Mo}^{4+}$ & $\mathrm{Mo}^{5+}$ & $\mathrm{Mo}^{6+}$ & $\mathrm{Mo}^{4+}$ & $\mathrm{Mo}^{5+}$ & $\mathrm{Mo}^{6+}$ \\
\hline $\mathrm{Mo} / \mathrm{Al}$ & 229.4 & - & 232.6 & 55.1 & 0 & 44.9 \\
\hline $\mathrm{K}-\mathrm{Mo} / \mathrm{Al}$ & 229.0 & 232.0 & 232.9 & 38.0 & 30.8 & 31.2 \\
\hline
\end{tabular}

Figure 10 shows the S(2p) XPS spectrum of the sulfided catalyst, in which $S_{H}$ represents the sulfur species of high valence state and $S_{L}$ represents the sulfur species of low valence state. Low-valent sulfur species can be classified into elements $\mathrm{S}(164.0 \mathrm{eV}), \mathrm{S}^{2-}(162.0 \mathrm{eV})$, $\mathrm{S}_{2}{ }^{2-}(162.5 \mathrm{eV})$, oxy-sulfides (162.3 163.2 eV) and polysulfides (162.9 164.4 eV) [56]. The high valence sulfur species is $\mathrm{SO}_{4}{ }^{2-}(169.1 \mathrm{eV})$, confirmed by the XRD experimental results. The XRD experimental results detected the existence of $\mathrm{K}_{2} \mathrm{SO}_{4}$ (Figure 3), caused by the oxidation of low-valent sulfur species by oxygen-containing species and other oxidants in the reaction system [16,18]. It can be seen from Figure 10 that the addition of $\mathrm{K}$ increases the quantities of the high-valence $S^{6+}$ species, while the low-valence sulfur species decreases (Figure 10). For the $\mathrm{MoS}_{2}$-based catalyst, it has been proved that low-valent sulfur ions such as $\mathrm{S}^{2-}$ and $\mathrm{S}_{2}{ }^{2-}$ can activate hydrogen $[57,58]$. In the process of reduction and sulfurization of oxidized Mo (VI) species to $\mathrm{Mo}^{5+}$ and $\mathrm{Mo}^{4+}$ species in $\mathrm{CS}_{2} / \mathrm{H}_{2}$ atmosphere, the coordination number of Mo-S and Mo-Mo in the sulfided catalyst is significantly less 
than that of the oxidized catalyst, and the surface reconstruction occurs, leading to the increase of Mo unsaturated coordination sites on the catalysts surface $[49,59]$, which is beneficial to the formation of methyl mercaptan.

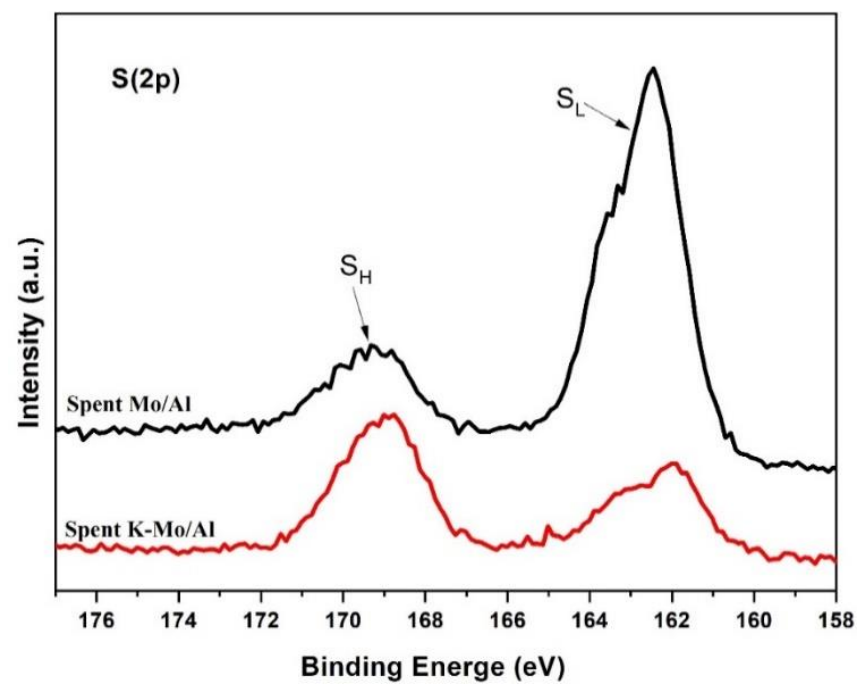

Figure 10. The $S(2 p)$ XPS spectra of the spent catalysts.

\subsection{Proposed Mechanism on the Acid-Base Site}

Combined with the activity test data of the catalysts and the aforementioned characterization results, illustrating the surface performance of the catalysts directly affects the distribution of the products. When alumina is treated with alkali, the Lewis acid site on the surface of the catalyst decreases rapidly, and the strong base site increases greatly, so the selectivity of $\mathrm{CH}_{3} \mathrm{SH}$ decreases significantly, and the selectivity of by-product $\mathrm{CH}_{3} \mathrm{SCH}_{3}$ increases greatly. This is mainly due to the strong adsorption of $\mathrm{CH}_{3} \mathrm{SH}$ on the surface of the catalyst, and $\mathrm{CH}_{3} \mathrm{SH}$ cannot be separated from the catalyst surface in time, which leads to the further disproportionation of $\mathrm{CH}_{3} \mathrm{SH}$ to $\mathrm{CH}_{3} \mathrm{SCH}_{3}$. Comparing the activity results of $\mathrm{Mo} / \mathrm{Al}$ and $\mathrm{Al}$ catalysts, the selectivity of $\mathrm{CH}_{3} \mathrm{SH}$ on $\mathrm{Mo} / \mathrm{Al}$ catalyst is slightly higher than that of $\mathrm{Al}$, because the introduction of Mo slightly increases the weak acidity site of the catalyst, which is beneficial to the formation of $\mathrm{CH}_{3} \mathrm{SH}$. After the simultaneous introduction of $\mathrm{K}$ and Mo, alkaline $\mathrm{K}$ and acidic Mo have a synergistic effect, which jointly regulates the acid-base sites on the surface of the catalyst, thus affecting the adsorption performance of the products on the catalyst surface, and cooperatively catalyzes the hydrogenation of $\mathrm{CS}_{2}$ to $\mathrm{CH}_{3} \mathrm{SH}$. XPS results show that the increase of $\mathrm{Mo}^{5+}$ species concentration on the $\mathrm{K}-\mathrm{Mo} / \mathrm{Al}$ catalyst leads to the increase of Mo coordination unsaturated sites on the catalyst surface, which is beneficial to the activation of $\mathrm{CS}_{2}[15,16,18]$. To sum up, as far as the synthesis of $\mathrm{CH}_{3} \mathrm{SH}$ by $\mathrm{CS}_{2}$ hydrogenation is concerned, we have concluded that the main active site of the catalysts is the weak Lewis acid-base site, and the strong acidic site and strong basic site are not conducive to the formation of $\mathrm{CH}_{3} \mathrm{SH}$. In addition, it is generally believed that the active phase for the synthesis of $\mathrm{CH}_{3} \mathrm{SH}$ over $\mathrm{K}$-promoted $\mathrm{MoS}_{2}$-based catalysts is the K-Mo-S phase $[8,10,11,16]$, but in this paper, we did not pre-sulfurization the catalyst before the reaction, so it can be considered that apart from the K-Mo-S phase, the K-Mo-O phase may also be the main active phase.

The possible reaction mechanism for the hydrogenation of $\mathrm{CS}_{2}$ to $\mathrm{CH}_{3} \mathrm{SH}$ is presented in Scheme 1. Firstly, the molecule $\mathrm{H}_{2}$ is dissociated and adsorbed on the two adjacent basic centers, while the $\mathrm{CS}_{2}$ molecule is non-dissociated and adsorbed on the acid site (Step I). The $\mathrm{S}=\mathrm{C}=\mathrm{S}$ double bond is broken and interacts with the nearby dissociated adsorbed $\mathrm{H}$ to produce the intermediate fragment HSCSH (Step II). Then, another molecule $\mathrm{H}_{2}$ is dissociated and adsorbed on the alkaline center (Step III), after the C-S bond breaks and rearranges, the intermediate fragment $\mathrm{HSCH}$ is formed, and a molecule of $\mathrm{H}_{2} \mathrm{~S}$ is 
released (Step IV). Finally, another molecule $\mathrm{H}_{2}$ is dissociated and adsorbed on the base center (Step V), and interacts with the intermediate fragment $\mathrm{HSCH}$ and rearranges to form $\mathrm{CH}_{3} \mathrm{SH}$, detached from the surface of the catalyst (step VI). As a result, the catalyst returns to its initial state.

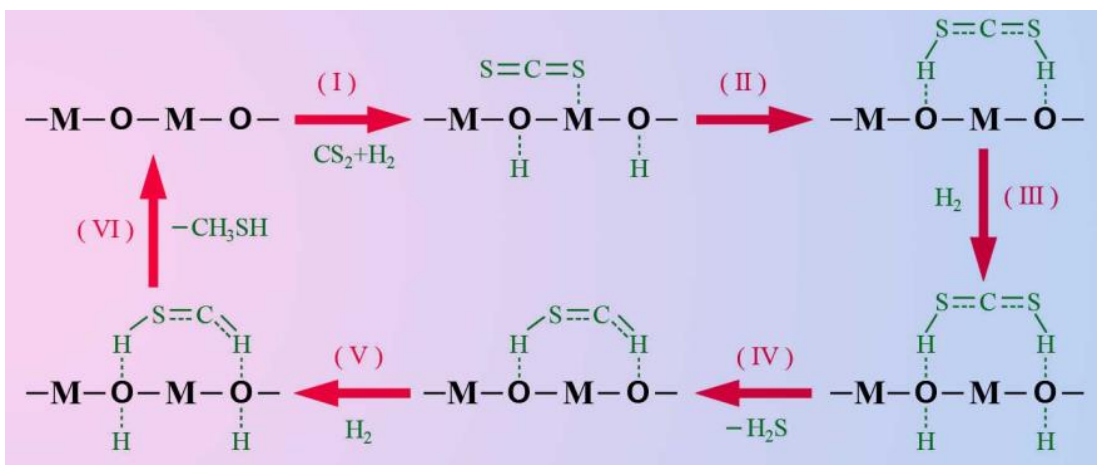

Scheme 1. Reaction mechanism for the hydrogenation of $\mathrm{CS}_{2}$ to $\mathrm{CH}_{3} \mathrm{SH}$ on the weak Lewis acid-base surface centers. ( $\mathbf{M}$ represents the Lewis acid centers and $\mathbf{O}$ represents the Lewis base centers).

\section{Experimental Section}

For the experimental section, including the preparation, activity tests and characterization of the catalysts, please refer to the Supporting Information for details.

\section{Conclusions}

In the present study, to further understand the effect of active components potassium and molybdenum on the selectivity of $\mathrm{CH}_{3} \mathrm{SH}$ and how they cooperate in the synthesis of $\mathrm{CH}_{3} \mathrm{SH}$, we chose $\mathrm{Al}_{2} \mathrm{O}_{3}$ as the support and supported active components potassium and molybdenum to prepare catalysts to study the one-step synthesis of $\mathrm{CH}_{3} \mathrm{SH}$ by $\mathrm{CS}_{2}$ hydrogenation. The introduction of alkali metal potassium alone will enhance the surface basicity of the catalyst and lead to the stronger adsorption of the product $\mathrm{CH}_{3} \mathrm{SH}$, which is beneficial to the formation of the by-product $\mathrm{CH}_{3} \mathrm{SCH}_{3}$. After loading potassium and molybdenum at the same time, the basic potassium species will interact with the acidic molybdenum species to coordinate the acid-base sites on the surface of the catalyst to promote the formation of $\mathrm{CH}_{3} \mathrm{SH}$. On the $\mathrm{K}-\mathrm{Mo} / \mathrm{Al}$ catalyst, the selectivity of $\mathrm{CH}_{3} \mathrm{SH}$ reached $91.2 \%$. The characterization results show that due to the interaction between $\mathrm{K}$ and Mo, some octahedral species are transformed into tetrahedral species, so the reducibility of molybdenum species decreases with the addition of $\mathrm{K}$, resulting in the $\mathrm{Mo}^{5+}$ species being more stable on the $\mathrm{K}-\mathrm{Mo} / \mathrm{Al}$ catalyst, while the $\mathrm{Mo}^{4+}$ species is more likely to be formed on the Mo/Al catalyst. In the process of reduction and sulfurization of oxidized Mo (VI) species to $\mathrm{Mo}^{5+}$ and $\mathrm{Mo}^{4+}$ species in the reaction atmosphere of $\mathrm{CS}_{2} / \mathrm{H}_{2}$, the coordination number of Mo-S and Mo-Mo in the sulfided catalyst decreased significantly compared with that of the oxidized catalyst, and the surface reconstruction occurred, which led to the increase of Mo unsaturated coordination sites on the catalyst surface, which was beneficial to the formation of $\mathrm{CH}_{3} \mathrm{SH}$. In addition, the catalysts were not pre-sulfurization before the reaction, but the presence of $\mathrm{MoS}_{2}$ was detected in the catalysts after the reaction, indicating that the catalysts can use the reaction atmosphere for self-sulfurization during the reaction. It is considered that apart from the K-Mo-S phase, the K-Mo-O phase may also be the main active phase.

Supplementary Materials: The following are available online at https:/ / www.mdpi.com/article / 10.3390/catal11111365/s1, Figure S1: The selectivities toward $\mathrm{CH}_{4}, \mathrm{CH}_{3} \mathrm{SCH}_{3}$ and $\mathrm{CH}_{3} \mathrm{SH}$ as a function of reaction temperature over the $\mathrm{Al}, \mathrm{Mo} / \mathrm{Al}, \mathrm{K} / \mathrm{Al}$ and $\mathrm{K}-\mathrm{Mo} / \mathrm{Al}$ catalysts. Reaction conditions: $\mathrm{P}=0.3 \mathrm{MPa}, \mathrm{R}\left(\mathrm{CS}_{2}\right)=1.6 \mathrm{~mL} / \mathrm{h}, \mathrm{R}\left(\mathrm{H}_{2}\right)=30 \mathrm{~mL} / \mathrm{min}, 2 \mathrm{~mL}$ of the Catalyst. Figure S2: Spectra of pyridine adsorbed on the catalysts at (a) $50{ }^{\circ} \mathrm{C}$, (b) $100{ }^{\circ} \mathrm{C}$, (c) $150{ }^{\circ} \mathrm{C}$, (d) $250{ }^{\circ} \mathrm{C}$. 
Author Contributions: Conception and design of experiments, W.W. and R.Q.; operation of the experiment, C.P. and D.Z.; data analysis, J.L., S.P. and J.X.; material characterization, Y.C., H.L. (Hong Liu) and H.L. (Hao Liu); writing-original draft preparation, C.P. and D.Z.; writing-review and editing, W.W. and R.Q. All authors have read and agreed to the published version of the manuscript.

Funding: This work was financially supported by the fund of the Key Laboratory of Catalysis and Energy Materials Chemistry of Ministry of Education \& Hubei Key Laboratory of Catalysis and Materials Science (CHCL20006), Science and Technology Research Project of Education Department of Hubei Province (Q20181711), the Major Technological Innovation of Hubei Province of China (2018ABA093), the Foundation of State Key Laboratory of Coal Combustion (FSKLCCA2109), and the Foundation of Hubei Provincial Engineering Laboratory for Clean Production and High Value Utilization of Bio-Based Textile Materials (SWJ202109).

Conflicts of Interest: There are no conflict to declare.

\section{References}

1. Zhang, Y.H.; Chen, S.P.; Wu, M.; Fang, W.P.; Yang, Y.Q. Promoting effect of $\mathrm{SiO}_{2}$ on the $\mathrm{K}_{2} \mathrm{WO}_{4} / \mathrm{Al}_{2} \mathrm{O}_{3}$ Catalysts for Methanethiol Synthesis from Methanol and $\mathrm{H}_{2}$ S. Catal. Commun. 2012, 22, 48-51. [CrossRef]

2. Bermejo-Deval, R.; Walter, R.M.H.; Gutiérrez, O.Y.; Lercher, J.A. On the Role of the Alkali Cations on Methanol Thiolation. Catal. Sci. Technol. 2017, 7, 4437-4443. [CrossRef]

3. Pashigreva, A.V.; Kondratieva, E.; Bermejo-Deval, R.; Gutiérrez, O.Y.; Lercher, J.A. Methanol thiolation over $\mathrm{Al}_{2} \mathrm{O}_{3}$ and $\mathrm{WS}_{2}$ catalysts modified with cesium. J. Catal. 2017, 345, 308-318. [CrossRef]

4. Weber-Stockbauer, M.; Gutiérrez, O.Y.; Bermejo-Deval, R.; Lercher, J.A. The Role of Weak Lewis Acid Sites for Methanol Thiolation. Catal. Sci. Technol. 2019, 9, 509-516. [CrossRef]

5. Weber-Stockbauer, M.; Gutiérrez, O.Y.; Bermejo-Deval, R.; Lercher, J.A. Cesium Induced Changes in the Acid-Base Properties of Metal Oxides and the Consequences for Methanol Thiolation. ACS Catal. 2019, 9, 9245-9252. [CrossRef]

6. Wang, Y.; Yang, T.L.; Liu, F.; Zhao, T.X.; Wang, X.D.; Cao, J.X. High selectivity in methanethiol synthesis over a coated composite comprising ZSM-5 with t-ZrO2. Microporous Mesoporous Mater. 2020, 305, 110358-110365. [CrossRef]

7. Mul, G.; Wachs, I.E.; Hirschon, A.S. Catalytic Synthesis of Methanethiol from Hydrogen Sulfide and Carbon Monoxide over Vanadium-based Catalysts. Catal. Today 2003, 78, 327-337. [CrossRef]

8. Yang, Y.Q.; Dai, S.J.; Yuan, Y.Z.; Lin, R.C.; Tang, D.L.; Zhang, H.B. The promoting effects of $\mathrm{La}_{2} \mathrm{O}_{3}$ and $\mathrm{CeO}_{2}$ on $\mathrm{K}_{2} \mathrm{MoS}_{4} / \mathrm{SiO}_{2}$ catalyst for methanethiol synthesis from synthesis gas blending with $\mathrm{H}_{2} \mathrm{~S}$. Appl. Catal. A 2000, 192, 175-180. [CrossRef]

9. Chen, A.P.; Wang, Q.; Li, Q.L.; Hao, Y.J.; Fang, W.P.; Yang, Y.Q. Direct synthesis of methanethiol from $\mathrm{H}_{2} \mathrm{~S}-$-rich syngas over sulfided Mo-based catalysts. J. Mol. Catal. A Chem. 2008, 283, 69-76. [CrossRef]

10. Lu, J.C.; Luo, Y.M.; He, D.D.; Xu, Z.Z.; He, S.F.; Xie, D.L.; Mei, Y. An exploration into potassium (K) containing MoS 2 active phases and its transformation process over $\mathrm{MoS}_{2}$ based materials for producing methanethiol. Catal. Today 2020, 339, 93-104. [CrossRef]

11. Yu, M.; Kosinov, N.; Haandel, L.V.; Kooyman, P.J.; Hensen, E.J.M. Investigation of the Active Phase in K-Promoted MoS 2 Catalysts for Methanethiol Synthesis. ACS Catal. 2020, 10, 1838-1846. [CrossRef]

12. Lu, J.C.; Liu, P.; Xu, Z.Z.; He, S.F.; Luo, Y.M. Investigation of the reaction pathway for synthesizing methyl mercaptan $\left(\mathrm{CH}_{3} \mathrm{SH}\right)$ from $\mathrm{H}_{2} \mathrm{~S}$-containing syngas over K-Mo-type materials. RSC Adv. 2018, 8, 21340-21353. [CrossRef]

13. Liu, P.; Lu, J.C.; Xu, Z.Z.; Liu, F.; Chen, D.K.; Yu, J.; Liu, J.P.; He, S.F.; Wan, G.P.; Luo, Y.M. The effect of alkali metals on the synthesis of methanethiol from $\mathrm{CO} / \mathrm{H}_{2} / \mathrm{H}_{2} \mathrm{~S}$ mixtures on the SBA-15 supported Mo-based catalysts. Mol. Catal. 2017, 442, 39-48. [CrossRef]

14. Cordova, A.; Blanchard, P.; Lancelot, C.; Frémy, G.; Lamonier, C. Probing the Nature of the Active Phase of MolybdenumSupported Catalysts for the Direct Synthesis of Methylmercaptan from Syngas and $\mathrm{H}_{2} \mathrm{~S}$. ACS Catal. 2015, 5, 2966-2981. [CrossRef]

15. Gutiérrez, O.Y.; Zhong, L.S.; Zhu, Y.Z.; Lercher, J.A. Synthesis of Methanethiol from $\mathrm{CS}_{2}$ on Ni-, $\mathrm{Co}^{-}$, and $\mathrm{K}-\mathrm{Doped} \mathrm{MoS}_{2} / \mathrm{SiO}_{2}$ Catalysts. ChemCatChem 2013, 5, 3249-3259. [CrossRef]

16. Gutiérrez, O.Y.; Kaufmann, C.; Lercher, J.A. Synthesis of Methanethiol from Carbonyl Sulfide and Carbon Disulfide on (Co)KPromoted Sulfide $\mathrm{Mo} / \mathrm{SiO}_{2}$ Catalysts. ACS Catal. 2011, 1, 1595-1603. [CrossRef]

17. Wang, W.M.; Zhang, X.; Xia, Z.Q.; Yang, Y.Q. Catalytic synthesis of methanethiol from carbon disulfide and hydrogen over sulfided $\mathrm{KMo} / \mathrm{Al}_{2} \mathrm{O}_{3}$ catalysts. Catal. Lett. 2015, 145, 1521-1528. [CrossRef]

18. Gutiérrez, O.Y.; Kaufmann, C.; Hrabar, A.; Zhu, Y.Z.; Lercher, J.A. Synthesis of methyl mercaptan from carbonyl sulfide over sulfide $\mathrm{K}_{2} \mathrm{MoO}_{4} / \mathrm{SiO}_{2}$. J. Catal. 2011, 280, 264-273. [CrossRef]

19. Wang, W.M.; Li, Y.; Zhang, X.; Fang, W.P.; Yang, Y.Q. Catalytic synthesis of methanethiol from methanol and carbon disulfide over $\mathrm{KW} / \mathrm{Al}_{2} \mathrm{O}_{3}$ catalysts. Catal. Commun. 2015, 69, 104-108. [CrossRef]

20. Wang, W.M.; Li, J.J.; He, Q.J.; Peng, S.; Li, M. Synthesis of methanethiol from methanol and carbon disulfide over CoKW $/ \mathrm{Al}_{2} \mathrm{O}_{3}$ catalysts: The possible reaction network and reaction mechanism. ChemistrySelect 2018, 3, 9663-9671. [CrossRef]

21. Lund, C.R.F. Microkinetics of Water-Gas Shift over Sulfided $\mathrm{Mo} / \mathrm{Al}_{2} \mathrm{O}_{3}$ Catalysts. Ind. Eng. Chem. Res. 1996, 35, 2531-2538. [CrossRef] 
22. Liu, B.; Zong, Q.Y.; Edwards, P.P.; Zou, F.; Du, X.; Jiang, Z.; Xiao, T.C.; AlMegren, H. Effect of Titania Addition on the Performance of $\mathrm{CoMo} / \mathrm{Al}_{2} \mathrm{O}_{3}$ Sour Water Gas Shift Catalysts under Lean Steam to Gas Ratio Conditions. Ind. Eng. Chem. Res. 2012, 51, 11674-11680. [CrossRef]

23. Zhu, T.; Liu, C.; Tan, X.Y.; Huang, B.; Bian, G.Q.; Shao, Q.; Bai, S.X.; Qian, Y.; Li, Y.Y.; Huang, X.Q. Se-Incorporation Stabilizes and Activates Metastable $\mathrm{MoS}_{2}$ for Efficient and Cost-Effective Water Gas Shift Reaction. ACS Nano 2019, 13, 11303-11309. [CrossRef] [PubMed]

24. Yun, S.U.; Guliants, V.V. Support Effects on Water Gas Shift Activity and Sulfur Dependence of Mo Sulfide Catalysts. Energy Fuels 2019, 33, 11655-11662. [CrossRef]

25. Ferrari, D.; Budroni, G.; Bisson, L.; Rane, N.J.; Dickie, B.D.; Kang, J.H.; Rozeveld, S.J. Effect of potassium addition method on $\mathrm{MoS}_{2}$ performance for the syngas to alcohol reaction. Appl. Catal. A-Gen. 2013, 462-463, 302-309. [CrossRef]

26. Hensley, J.E.; Pylypenko, S.; Ruddy, D.A. Deactivation and stability of K-CoMoS $x$ mixed alcohol synthesis catalysts. J. Catal. 2014, 309, 199-208. [CrossRef]

27. Dorokhov, V.S.; Permyakov, E.A.; Nikulshin, P.A.; Maximov, V.V.; Kogan, V.M. Experimental and computational study of syngas and ethanol conversion mechanisms over K-modified transition metal sulfide catalysts. J. Catal. 2016, 344, 841-853. [CrossRef]

28. Santos, V.P.; Linden, B.V.D.; Chojecki, A.; Budroni, G.; Corthals, S.; Shibata, H.; Meima, G.R.; Kapteijn, F.; Makkee, M.; Gascon, J. Mechanistic Insight into the Synthesis of Higher Alcohols from Syngas: The Role of K Promotion on $\mathrm{MoS}_{2}$ Catalysts. ACS Catal. 2013, 3, 1634-1637. [CrossRef]

29. Zhang, L.F.; Ball, M.R.; Rivera-Dones, K.R.; Wang, S.C.; Kuech, T.F.; Huber, G.W.; Hermans, I.; Dumesic, J.A. Synthesis Gas Conversion over Molybdenum-Based Catalysts Promoted by Transition Metals. ACS Catal. 2020, 10, 365-374. [CrossRef]

30. Maximov, V.V.; Permyakov, E.A.; Dorokhov, V.S.; Wang, A.J.; Kooyman, P.J.; Kogan, V.M. Effect of Promoter Nature on Synthesis Gas Conversion to Alcohols over $(\mathrm{K}) \mathrm{MeMoS}_{2} / \mathrm{Al}_{2} \mathrm{O}_{3}$ Catalysts. ChemCatChem 2020, 12, 1443-1452. [CrossRef]

31. Shi, G.J.; Zhao, H.Y.; Song, L.G.; Shen, J.Y. Effect of Solvents on the Hydrogenation and Isomerization of 1-Hexene over Sulfided $\mathrm{Co}-\mathrm{Mo} / \gamma-\mathrm{Al}_{2} \mathrm{O}_{3}$ Catalysts for Hydrodesulfurization. Energy Fuels 2008, 22, 2450-2454. [CrossRef]

32. Gutiérrez, O.Y.; Singh, S.; Schachtl, E.; Kim, J.; Kondratieva, E.; Hein, J.; Lercher, J.A. Effects of the Support on the Performance and Promotion of (Ni) $\mathrm{MoS}_{2}$ Catalysts for Simultaneous Hydrodenitrogenation and Hydrodesulfurization. ACS Catal. 2014, 4 , 1487-1499. [CrossRef]

33. Shi, Y.; Wang, G.; Mei, J.L.; Xiao, C.K.; Hu, D.; Wang, A.C.; Song, Y.D.; Ni, Y.; Jiang, G.Y.; Duan, A.J. The Influence of Pore Structure and Acidity on the Hydrodesulfurization of Dibenzothiophene over NiMo-Supported Catalysts. ACS Omega 2020, 5, 15576-15585. [CrossRef]

34. Mundotiya, S.; Singh, R.; Saha, S.; Kakkar, R.; Pal, S.; Kunzru, D.; Pala, R.G.S.; Sivakumar, S. Effect of Sodium on Ni-Promoted $\mathrm{MoS}_{2}$ Catalyst for Hydrodesulfurization Reaction: Combined Experimental and Simulation Study. Energy Fuels 2021, 35, 2368-2378. [CrossRef]

35. Liu, C.; Virginie, M.; Griboval-Constant, A.; Khodakov, A.Y. Potassium promotion effects in carbon nanotube supported molybdenum sulfide catalysts for carbon monoxide hydrogenation. Catal. Today 2016, 261, 137-145. [CrossRef]

36. Claure, M.T.; Morrill, M.R.; Goh, J.W.; Chai, S.H.; Dai, S.; Agrawal, P.K.; Jones, C.W. Insight into reaction pathways in CO hydrogenation reactions over $\mathrm{K} / \mathrm{MoS}_{2}$ supported catalysts via alcohol/olefin co-feed experiments. Catal. Sci. Technol. 2016, 6, 1957-1966. [CrossRef]

37. Zeng, F.; Xi, X.Y.; Cao, H.T.; Pei, Y.T.; Heeres, H.J.; Palkovits, R. Synthesis of mixed alcohols with enhanced $\mathrm{C}^{3+}$ alcohol production by CO hydrogenation over potassium promoted molybdenum sulfide. Appl. Catal. B-Environ. 2019, 246, 232-241. [CrossRef]

38. Hu, J.; Yu, L.; Deng, J.; Wang, Y.; Cheng, K.; Ma, C.; Zhang, Q.; Wen, W.; Yu, S.; Pan, Y.; et al. Sulfur vacancy-rich MoS 2 as a catalyst for the hydrogenation of $\mathrm{CO}_{2}$ to methanol. Nat. Catal. 2021, 4, 242-250. [CrossRef]

39. Yang, Y.Q.; Yuan, Y.Z.; Dai, S.J.; Wang, B.; Zhang, H.B. The catalytic properties of supported $\mathrm{K}_{2} \mathrm{MoS}_{4} / \mathrm{SiO}_{2}$ catalyst for methanethiol synthesis from high $\mathrm{H}_{2} \mathrm{~S}$-content synthesis gas. Catal. Lett. 1998, 54, 65-68. [CrossRef]

40. Dai, S.J.; Yang, Y.Q.; Yuan, Y.Z.; Tang, D.L.; Lin, R.C.; Zhang, H.B. On methanethiol synthesis from $\mathrm{H}_{2} \mathrm{~S}$-containing synthesis gas over $\mathrm{K}_{2} \mathrm{MoS}_{4} / \mathrm{SiO}_{2}$ catalysts promoted with transition metal oxides. Catal. Lett. 1999, 61, 157-160. [CrossRef]

41. Chen, A.P.; Wang, Q.; Hao, Y.J.; Fang, W.P.; Yang, Y.Q. The Promoting Effect of Tellurium on $\mathrm{K}_{2} \mathrm{MoO}_{4} / \mathrm{SiO}_{2}$ Catalyst for Methanethiol Synthesis from High $\mathrm{H}_{2} \mathrm{~S}$-containing Syngas. Catal. Lett. 2007, 118, 295-299. [CrossRef]

42. Chen, A.P.; Wang, Q.; Hao, Y.J.; Fang, W.P.; Yang, Y.Q. Catalytic Synthesis of Methanethiol from $\mathrm{H}_{2}$ S-rich Syngas Over Sulfided $\mathrm{SiO}_{2}$-supported Mo-based Catalysts. Catal. Lett. 2008, 121, 260-265. [CrossRef]

43. Zhang, L.; Zhu, H.; Ke, J.; Qin, R. Selection of a Taxon-Specific Reference Gene for Qualitative and Quantitative PCR Detection of Carthamus tinctorius. Food Anal. Methods 2017, 10, 2952-2963. [CrossRef]

44. Wu, Z.; Liu, H.; Zhan, W.; Yu, Z.; Qin, E.; Liu, S.; Yang, T.; Xiang, N.; Kudrna, D.; Chen, Y.; et al. The chromosome-scale reference genome of safflower (Carthamus tinctorius) provides insights into linoleic acid and flavonoid biosynthesis. Plant Biotechnol. J. 2021, 19, 1725-1742. [CrossRef] [PubMed]

45. Brito, J.L.; Laine, J. Reducibility of Ni-Mo/ $\mathrm{Al}_{2} \mathrm{O}_{3}$ catalysts: A TPR study. J. Catal. 1993, 139, 540-550. [CrossRef]

46. Feng, L.; Li, X.; Dadyburjor, D.B.; Kugler, E.L. A temperature-programmed-reduction study on alkali-promoted, carbon-supported molybdenum catalysts. J. Catal. 2000, 191, 1-13. [CrossRef]

47. Arnoldy, P.; de Jonge, J.C.M.; Moulijn, J.A. Temperature-programed reduction of molybdenum(VI) oxide and molybdenum(IV) oxide. J. Phys. Chem. 1985, 89, 4517-4526. [CrossRef] 
48. DeCanio, S.J.; Cataldo, M.C.; DeCanio, E.C.; Storm, D.A. Evidence from XPS for the stabilization of high-valent molybdenum by addition of potassium in $\mathrm{Mo} / \mathrm{Al}_{2} \mathrm{O}_{3}$ catalysts. J. Catal. 1989, 119, 256-260. [CrossRef]

49. Tatsumi, T.; Muramatsu, A.; Yokota, K.; Tominaga, H. Mechanistic study on the alcohol synthesis over molybdenum catalysts: Addition of probe molecules to CO-H 2 . J. Catal. 1989, 115, 388-398. [CrossRef]

50. Watson, R.B.; Ozkan, U.S. Propane and propylene adsorption effects over $\mathrm{MoO}_{\mathrm{x}}$-based catalysts induced by low levels of alkali doping. J. Mol. Catal. A 2003, 194, 115-135. [CrossRef]

51. Chen, K.; Xie, S.; Bell, A.T.; Iglesia, E. Alkali Effects on Molybdenum Oxide Catalysts for the Oxidative Dehydrogenation of Propane. J. Catal. 2000, 195, 244-252. [CrossRef]

52. Rajagopal, S.; Marzari, J.A.; Miranda, R. Silica-alumina-supported Mo oxide catalysts: Genesis and demise of Brønsted-Lewis acidity. J. Catal. 1995, 151, 192-203. [CrossRef]

53. Baker, M.A.; Gilmore, R.; Lenardi, C.; Gissler, W. XPS investigation of preferential sputtering of S from MoS 2 and determination of $\operatorname{MoS}_{\mathrm{x}}$ stoichiometry from Mo and S peak positions. Appl. Surf. Sci. 1999, 150, 255-262. [CrossRef]

54. Brown, N.M.D.; Cui, N.; McKinley, A. An XPS study of the surface modification of natural $\mathrm{MoS}_{2}$ following treatment in an RF-oxygen plasma. Appl. Surf. Sci. 1998, 134, 11-21. [CrossRef]

55. Kantschewa, M.; Delannay, F.; Jeziorowski, H.; Delgado, E.; Eder, S. Nature and properties of a potassium-promoted $\mathrm{NiMo} / \mathrm{Al}_{2} \mathrm{O}_{3}$ water gas shift catalyst. J. Catal. 1984, 87, 482-496. [CrossRef]

56. Spevack, P.A.; McIntyre, S. Reactivity and stability of sulphided thin films of molybdenum to dry air. Appl. Catal. 1990, 64, 191-207. [CrossRef]

57. Byskov, L.S.; Bollinger, M.; Nørskov, J.K.; Clausen, B.S.; Topsøe, H. Molecular aspects of the $\mathrm{H}_{2}$ activation on MoS 2 based catalysts-The role of dynamic surface arrangements. J. Mol. Catal. A 2000, 163, 117-122. [CrossRef]

58. Startsev, A.N.; Zakharov, I.I.; Parmon, V.N. An unexpected phenomenon in heterogeneous catalysis: Oxidative addition of hydrogen to the sulfide catalysts. J. Mol. Catal. A 2003, 192, 113-127. [CrossRef]

59. Bian, G.Z.; Fu, Y.L.; Yamada, M. Reaction stability and structure studies of sulfided $\mathrm{K}-\mathrm{MoO}_{3} / \gamma-\mathrm{Al}_{2} \mathrm{O}_{3}$ catalyst for the synthesis of mixed alcohols. Appl. Catal. A 1996, 144, 79-91. [CrossRef] 